\title{
Yield, Soil Nitrogen Uptake, and Nitrogen Fixation by Soybean from Four Maturity Groups Grown at Three Elevations
}

\author{
Thomas George,* Paul W. Singleton, and B. Ben
}

\begin{abstract}
The exploitation of the soybean [Glycine $\max (L$.) Merr.] -Bradyrhizobium japonicum symbiosis in varied environments requires an understanding of factors that may affect fixed and soil $\mathbf{N}$ assimilation. Temperature affects both soybean maturity and $\mathbf{N}$ requirement, and soil $N$ availability. Five soybean varieties belonging to four maturity groups $(00, \mathrm{IV}, \mathrm{VI}$, and VIII) and their respective nonnodulating isolines were planted at three sites along an elevational transect in Hawaii to study the effect of elevation-associated changes in temperature on yield, soil $\mathrm{N}$ uptake, and $\mathrm{N}=$ fixation. The mean soil/air temperatures during the experiment were $24 / 23,23 / 21$, and $20 / \mathrm{IS}{ }^{\circ} \mathrm{C}$, with 7,8 , and $9^{\circ} \mathrm{C}$ differentials between mean maximum and mean minimum air temperatures at elevations of 320,660 , and $1050 \mathrm{~m}$, respectively. The soils of the two lower sites were Humoxic Tropohumults and that of the highest site was Entic Dystrandept. The seeds were inoculated at planting with $B$. japonicum. Plants were harvested at physiological maturity. Average dry matter yield and $N$ accumulation at the highest site was only 48 and $41 \%$, respectively, of that at the lowest site. Early maturing varieties were relatively more affected by high elevation than were later varieties. Within each site, late-maturing varieties produced greater yield and accumulated more $\mathbf{N}$ than did the early varieties. Nitrogen fixation contributed 80,66 , and $97 \%$ to total plant $\mathrm{N}$ at the lowest, intermediate, and highest sites, respectively. Differences between sites in the proportion of $\mathrm{N}$ from fixation we re due to differences in the availability and uptake of soil $\mathbf{N}$. Although total $\mathbf{N}$ assimilation between varieties differed in some cases by more than $400 \%$, the proportions of $\mathrm{N}$ derived from fixation were similar within a site. On a per-day basis, $\mathrm{N}$ accumulation was similar among varieties at a site. Since the different maturity groups had similar average $\mathrm{N}$ assimilation rates per day within a site, and since soil $\mathrm{N}$ mineralization rate per day at a site can be assumed to be constant, the proportion of total $\mathbf{N}$ derived from $\mathrm{N}_{2}$ fixation is necessarily constant. Since the proportion of $\mathbf{N}$ derived from fixation is yield independent at a site, it may be possible to predict the relative contributions of soil $\mathbf{N}$ and symbiotic $\mathrm{N}_{2}$ fixation to soybean through characterization of the processes that affect $N$ availability at a site. Data from in vitro soil $\mathrm{N}$ mineralization and a greenhouse pot test indicated that low temperature may have decreased root growth and uptake of soil $\mathbf{N}$, or soil $\mathbf{N}$ availability more than it reduced $\mathbf{N}_{2}$ fixation.

Additional Index Words: Glycine max, Temperature, Non-nodulating isoline, Symbiotic nitrogen fixation, Bradyrhizobium japonicum.
\end{abstract}

Soybean plants can acquire a substantial portion of their $\mathrm{N}$ requirements from symbiotic association with Bradyrhizobium japonicum. Both management and environmental variables affect the symbiosis. Any factor that affects the availability and plant uptake of soil $\mathrm{N}$ could directly influence $\mathrm{N}_{2}$ fixation and soybean yield. An understanding of factors that may differentially affect fixed and soil $\mathrm{N}$ assimilation would enable better exploitation of the symbiosis.

Temperature is an important environmental variable that influences symbiotic and soil- $\mathrm{N}$ assimilation by soybean and other legumes. Increasing root temperature within the range of 15 to $27^{\circ} \mathrm{C}$ has been shown 'to increase growth and dry matter production in soy- bean (Earley and Canter, 1945; Matthews and Hayes, 1982; Trang and Giddens, 1980). Lowering both root and shoot temperature from 25 to $10^{\circ} \mathrm{C}$ decreased photosynthesis in soybean more than reducing shoot temperature alone (Taylor and Rowley, 1971). Exposing the soybean shoot alone to low temperature $\left(18^{\circ} \mathrm{C}\right)$, however, has an effect on nodule activity comparable to reducing both root and shoot temperatures (Schweitzer and Harper, 1980). Harding and Sheehy (1980) showed that leaf growth of lucerne (Medicago saliva) was correlated with air temperature, while $\mathrm{N}_{2}$ fixation was correlated with root temperature. Soil-N mineralization (Stanford et al., 1973; Cassman and Munns, 1980) and root uptake of mineralized N (Tolley and Raper, 1985) are also functions of temperature. Therefore, temperature may directly and indirectly affect growth of soybean through effects on photosynthesis, N uptake, and $\mathrm{N}_{2}$ fixation. Raper et al. (1977) suggested that temperature mediates a balance between $\mathrm{N}$ assimilation and photosynthate supply.

Due to the strong photoperiod sensitivity of soybean (Bonhwick and Parker, 1939), assessment of temperature effects on productivity under field conditions is often difficult. In North American soybean production regions, average temperatures in many circumstances are a function of latitude, which confounds the temperature variable with photoperiod and irradiance.

The present investigation was undertaken to evaluate the effect of temperature on yield, soil $\mathrm{N}$ uptake, and $\mathrm{N}_{2}$ fixation by soybean varieties from four maturity groups. By planting several varieties from a range of maturity groups at field sites along an elevational transect on the island of Maui, HI, we were able to minimize the effects of photoperiod and its associated influence on irradiance on soybean growth and development.

\section{MATERIALS AND METHODS \\ Field and Plant Culture \\ Five nodulating (nod) and non-nodulating (non-nod) isolines of soybean representing four maturity groups (00, IV, VI, and VIII) were used in the study. The isolines and their maturity groups and sources were: Clay 00, J.H. Orf, Agronomy and Plant Genetics, University of Minnesota; Clark IV, P. Cregan, USDA Nitrogen Fixation Laboratory, Beltsville; D68-0099 VI nod, D68-0102 VI non-nod, N77-4262 VI nod, and N77-4273 VI non-nod (determinate and indeterminate selections from the cultivar Lee), T. E. Carter, Department of Crop Science, North Carolina State University; and Hardee VIII, K. Hinson, Department of Agron-}

NifT AL Project, Dep. of Agronomy and Soil Sci., Univ. of Hawaii, 1000 Holomua Ave., Paia, H I 96779-9744. Joumal Series no. 3213 of the Hawaii Inst. of Tropical Agric. and Human Resources. Received 7 Aug. 1987. *Comesponding author.

Published in Agron. J. 80:563-567 (1988). 
Table 1. Characteristics of three sites in an elevational transect on the island of Maui, HI. $\dagger$

\begin{tabular}{|c|c|c|c|c|c|c|c|}
\hline \multirow[b]{3}{*}{ Site (elevation, m) } & \multirow[b]{3}{*}{ Soil classification } & \multirow[b]{3}{*}{ Rainfall } & \multicolumn{4}{|c|}{ Temperature } & \multirow[b]{3}{*}{ Irradiance } \\
\hline & & & \multirow{2}{*}{$\begin{array}{c}\text { Soil } \\
\text { (10-cm depth) }\end{array}$} & \multicolumn{3}{|c|}{ Air } & \\
\hline & & & & Max. & Min. & Mean & \\
\hline & & mm & & & ${ }^{\circ} \mathbf{C}$ & - & $\mathbf{W} \mathbf{m}^{-2}$ \\
\hline Kuiaha (320) & Clayey, ferritic, isohyperthermic & & & & & & \\
\hline Haleakala $(660)$ & $\begin{array}{l}\text { Humoxic Tropohumult } \\
\text { Clayey, oxidic, isothermic }\end{array}$ & 415 & 24.4 & 26.5 & 19.7 & 22.6 & 262 \\
\hline Olinda (1050) & $\begin{array}{l}\text { Humoxic Tropohumult } \\
\text { Medial over loamy-skeletal, isomesic }\end{array}$ & 407 & 22.6 & 25.4 & 17.0 & 20.6 & 211 \\
\hline & Entic Dystrandept & 678 & 19.6 & 22.7 & 13.9 & 17.8 & 194 \\
\hline
\end{tabular}

† All data averaged across the crop duration of all five varieties at a site.

omy, University of Florida. Seeds were planted on 29 July 1985 at 320,660 , and $1050 \mathrm{~m}$ on the island of Maui, HI. The three sites were part of an elevational transect of the Maui Experimental Network (MauiNet) and are described in Table 1. Weather data were recorded by Campbell Scientific' CR-21 micrologger (Campbell Scientific, Inc., Logan, UT) equipped with sensing probes for temperature (Fenwal' thermistor; Fenwal Electronics, Milford, MA) and irradiance (Li-Cor' LI 200S ZC silicon pyranometer; Li-Cor, Inc., Lincoln, NE). The micrologger is programmed to record data at 1-min intervals and integrate into daily and monthly means. Soil $\mathrm{pH}$ was adjusted as necessary (5.5-6.0), and nonlimiting amounts of nutrients, except $\mathrm{N}$, were applied as described by George et al. (1987). Seeds of nod isolines were inoculated with equal numbers of Bradyrhizobium japonicum strains USDA 110, USDA 136b, and USDA 138 as described previously (George et al., 1987). Seeds were sown in 4 by $2.4-\mathrm{m}$ plots with $60-\mathrm{cm}$ rows (four rows per plot) to achieve a final population of 400000 plant ha '. The fields were irrigated the day of planting to a moisture tension of $3.0 \times 10^{4} \mathrm{~Pa}$ and maintained near that tension over the course of the study with the aid of tensiometers.

\section{Sampling Procedures}

Three meters of row from the center of the two interior rows were harvested at or near physiological maturity. Both nod and non-nod isolines were harvested at the same time. Plants were cut at the soil surface, and fresh weight for each plot was recorded. A fresh-weight subsample (15-25 plants) was then taken for dry weight determination. Samples were

Table 2. Grain and stover yield of five nodulating soybean varieties grown at three different elevations.

\begin{tabular}{|c|c|c|c|c|c|c|}
\hline \multirow[b]{2}{*}{$\begin{array}{l}\text { Site } \\
\text { (elevation, m) }\end{array}$} & \multicolumn{5}{|c|}{ Varieties } & \multirow[b]{2}{*}{ Mean } \\
\hline & $\begin{array}{c}\text { Clay } \\
00 \dagger\end{array}$ & $\begin{array}{c}\text { Clark } \\
\text { IV }\end{array}$ & $\begin{array}{c}\text { D68- } \\
0099 \\
\text { VI }\end{array}$ & $\begin{array}{c}\text { N77- } \\
4262 \\
\text { VI } \\
\end{array}$ & $\begin{array}{c}\text { Hardee } \\
\text { VIII }\end{array}$ & \\
\hline & \multicolumn{6}{|c|}{$\longrightarrow \mathrm{kg} \mathrm{ha^{-1 }}$} \\
\hline Kuiaha (320) & $\begin{array}{l}3223 \\
(3105) \ddagger\end{array}$ & $\begin{array}{c}4424 \\
(3859)\end{array}$ & $\begin{array}{c}4273 \\
(3661)\end{array}$ & $\begin{array}{c}3530 \\
(3265)\end{array}$ & $\begin{array}{c}4833 \\
(4117)\end{array}$ & $\begin{array}{r}\text { 4057A } \$ \\
\text { (3601A) }\end{array}$ \\
\hline Haleakala (660) & $\begin{array}{c}2803 \\
(2891)\end{array}$ & $\begin{array}{l}3066 \\
(3381)\end{array}$ & $\begin{array}{c}3721 \\
(3763)\end{array}$ & $\begin{array}{c}3526 \\
(3829)\end{array}$ & $\begin{array}{c}3601 \\
(4060)\end{array}$ & $\begin{array}{c}\text { 3344B } \\
\text { (3585A) }\end{array}$ \\
\hline Olinda $(1050)$ & $\begin{array}{c}517 \\
(\mathbf{5 8 5 )}\end{array}$ & $\begin{array}{c}1357 \\
(1389)\end{array}$ & $\begin{array}{c}1903 \\
(2088)\end{array}$ & $\begin{array}{c}2580 \\
(2496)\end{array}$ & $\begin{array}{c}1877 \\
(2534)\end{array}$ & $\begin{array}{c}1647 \mathrm{C} \\
(1819 \mathrm{~B})\end{array}$ \\
\hline Mean & $\begin{array}{l}\text { 2181d } \\
\text { (2194d) }\end{array}$ & $\begin{array}{c}2949 \mathrm{c} \\
(2877 \mathrm{c})\end{array}$ & $\begin{array}{c}\text { 3299ab } \\
\text { (3171b) }\end{array}$ & $\begin{array}{l}3212 b \\
(3197 b)\end{array}$ & $\begin{array}{c}3437 a \\
(3570 a)\end{array}$ & \\
\hline
\end{tabular}

+ Indicates maturity group designation of the variety.

¥Values in parentheses are stover yields.

$\S$ Data followed by the same letter within the column or row are not significantly different $(P=0.05)$ by Duncan's Multiple Range test.

'Mention of a brand name does not constitute an endorsement by the authors, the University of Hawaii, or USAID. dried at $70^{\circ} \mathrm{C}$ and separated into grain and stover. Total $\mathrm{N}$ was determined on ground samples digested in $\mathrm{H}_{2} \mathrm{SO}_{4}$ after pre-treatment with $\mathrm{H}_{2} \mathrm{O}_{2}$ (Parkinson and Allen, 1975). Ammonium was measured in the digests by the indophenol blue method (Keeny and Nelson, 1982). The amount of $\mathrm{N}$ fixed was estimated by substracting total $\mathrm{N}$ in the non-nod isoline from its nod counterpart.

\section{In Vitro Soil Nitrogen Mineralization}

Soil samples to a depth of $20 \mathrm{~cm}$ were collected from the three sites at planting to determine $\mathrm{N}$ mineralization potential. Samples of approximately $20 \mathrm{~g}$ of air-dry soil were saturated and then equilibrated by pressure plate at $3.0 \times 10^{\circ} \mathrm{Pa}$ for initial analysis and incubation (Cassman and Munns, 1980). Triplicate samples were extracted with $200 \mathrm{~mL}$ of $2 \mathrm{M} \mathrm{KCI}$, before and after incubation at $25^{\circ} \mathrm{C}$, in $250-\mathrm{mL}$ flasks for 2 wk. Flasks were covered with aluminum foil that was pierced with two pinholes. Water loss was negligible during incubation. Nitrate and $\mathrm{NH}_{4}-\mathrm{N}$ were determined from the filtered extracts by cadmium reduction and indophenol blue methods, respectively (Keeny and Nelson, 1982).

\section{Greenhouse Experiment}

Clark non-nod soybean was grown in pots (two plants per pot, four replications) containing. $4 \mathrm{~kg}$ of soil (oven-dry basis) from each of the three sites to measure plant uptake of $\mathrm{N}$ from the soils under a constant temperatute regime. Pots were maintained at 3.0 $\mathrm{X} 10^{4} \mathrm{~Pa}$ tension by watering to a pre-determined constant weight. The mean soil temperature during the experiment was $27^{\circ} \mathrm{C}$. At 45 $\mathrm{d}$ from planting, plants were cut at the soil surface and analyzed for total $\mathrm{N}$ as described previously.

\section{Experimental Design and Data Analysis}

The field experiment was a randomized complete-block design with nod and non-nod isolines of the five varieties replicated three times at each site. The data from the three

Table 3. Total $\mathbf{N}$ accumulation by five nodulating soybean varieties grown at three different elevations.

\begin{tabular}{|c|c|c|c|c|c|c|}
\hline \multirow[b]{2}{*}{$\begin{array}{l}\text { Site } \\
\text { (elevation, m) }\end{array}$} & \multicolumn{5}{|c|}{ Varieties } & \multirow[b]{2}{*}{ Mean } \\
\hline & $\begin{array}{r}\text { Clay } \\
00^{\dagger} \\
\end{array}$ & $\begin{array}{c}\text { Clark } \\
\text { IV }\end{array}$ & $\begin{array}{c}\text { D68- } \\
0099 \\
\text { VI }\end{array}$ & $\begin{array}{c}\text { N77- } \\
4262 \\
\text { VI } \\
\end{array}$ & $\begin{array}{c}\text { Hardee } \\
\text { VIII }\end{array}$ & \\
\hline & \multicolumn{6}{|c|}{ - $k g \mathrm{ha}^{-1}$} \\
\hline $\begin{array}{l}\text { Kuiaha }(320) \\
\text { Haleakala }(660) \\
\text { Olinda }(1050)\end{array}$ & $\begin{array}{r}236 \\
199 \\
44\end{array}$ & $\begin{array}{r}317 \\
246 \\
99\end{array}$ & $\begin{array}{l}316 \\
271 \\
128\end{array}$ & $\begin{array}{l}260 \\
258 \\
186\end{array}$ & $\begin{array}{l}349 \\
276 \\
144\end{array}$ & $\begin{array}{l}295 A \ddagger \\
250 B \\
120 C\end{array}$ \\
\hline Mean & $160 \mathrm{~d} t$ & 221c & $\mathbf{2 3 8 b}$ & $234 b c$ & $256 a$ & \\
\hline
\end{tabular}

$\uparrow$ Indicates maturity group designation of the variety.

$\ddagger$ Data followed by the same letter within the column or row are not significantly different $(P=0.05)$ by Duncan's Multiple Range test. 
Table 4. Symbiotically fixed $\mathbf{N}$ by five soybean varieties grown at three different elevations.

\begin{tabular}{|c|c|c|c|c|c|c|}
\hline \multirow[b]{2}{*}{$\begin{array}{l}\text { Site } \\
\text { (elevation, m) }\end{array}$} & \multicolumn{5}{|c|}{ Varieties } & \multirow[b]{2}{*}{ Mean } \\
\hline & $\begin{array}{l}\text { Clay } \\
00 \dagger\end{array}$ & $\begin{array}{c}\text { Clark } \\
\text { IV }\end{array}$ & $\begin{array}{l}\text { D68- } \\
0099 \\
\text { VI }\end{array}$ & $\begin{array}{l}\text { N77. } \\
4262 \\
\text { VI }\end{array}$ & $\begin{array}{c}\text { Hardiee } \\
\text { VIII }\end{array}$ & \\
\hline & \multicolumn{6}{|c|}{$\longrightarrow \mathrm{kg} \mathrm{ha-1}$} \\
\hline $\begin{array}{l}\text { Kuiaha }(320) \\
\text { Haleakala (660) } \\
\text { Olinda (1050) }\end{array}$ & $\begin{array}{r}199 \\
122 \\
42\end{array}$ & $\begin{array}{r}258 \\
175 \\
97\end{array}$ & $\begin{array}{l}268 \\
176 \\
125\end{array}$ & $\begin{array}{l}180 \\
169 \\
183\end{array}$ & $\begin{array}{l}281 \\
188 \\
139\end{array}$ & $\begin{array}{l}237 \mathrm{At} \\
166 \mathrm{~B} \\
117 \mathrm{C}\end{array}$ \\
\hline Mean & 121c $\ddagger$ & $177 \mathrm{~b}$ & $190 \mathrm{ab}$ & $177 b$ & $203 a$ & \\
\hline
\end{tabular}

$\dagger$ Indicates maturity group designation of the variety.

¥ Data followed by the same letter within the column or row are not significantly different $(P=0.05)$ by Duncan's Multiple Range test.

sites were combined (McIntosh, 1983) and subjected to analysis of variance using SAS procedures (SAS Institute, 1982).

\section{RESULTS}

Irradiance at the 660- and 1050-m elevations was 80 and 7596 of that at the 320-m elevation (Table 1). Mean soil and mean air temperatures declined approximately $5^{\circ} \mathrm{C}$ from the lowest to the highest site. The mean maximum and mean minimum air temperatures differed by 7,8 , and $9^{\circ} \mathrm{C}$ at the lowest, intermediate, and highest sites, respectively.

There were significant differences in grain and stover yields between sites and varieties (Table 2). Average grain and stover yields at the highest site were only 41 and 5196, respectively, of those at the lowest site. Yields were reduced at higher elevations to a greater extent in the early maturing varieties, Clay and Clark, than in later maturing varieties. In general, yields increased with maturity group number at a site. Variety N77-4262, an indeterminate maturity group VI entree, was less affected by elevation than were other varieties. Variety Hardee produced the highest average yield.

Total $\mathrm{N}$ accumulation and amounts of $\mathrm{N}$ fixed decreased with increasing elevation (Tables 3 and 4). The effect of elevation was relatively greater on the early maturing variety, Clay. Total $\mathrm{N}$ and fixed $\mathrm{N}$ increased with increasing maturity group number. Varietal differences in rates of $\mathrm{N}$ assimilation within sites were relatively small compared to effects of elevation (Table 5).

The relative contributions from symbiotic $\mathrm{N}_{2}$ fixation and soil $\mathrm{N}$ uptake to total $\mathrm{N}$ were significantly different between sites (Table 6), but relatively con-

Table 6. Percent of total $\mathbf{N}$ derived from symbiotic fixation by five soybean varieties grown at three different elevations.

\begin{tabular}{|c|c|c|c|c|c|c|}
\hline \multirow[b]{2}{*}{$\begin{array}{l}\text { Site } \\
\text { (elevation, m) }\end{array}$} & \multicolumn{5}{|c|}{ Varieties } & \multirow[b]{2}{*}{ Mean } \\
\hline & $\begin{array}{l}\text { Clay } \\
00 \dagger\end{array}$ & $\begin{array}{c}\text { Clark } \\
\text { IV }\end{array}$ & $\begin{array}{l}\text { D68- } \\
\text { Cog9 } \\
\text { VI }\end{array}$ & $\begin{array}{l}\text { N77- } \\
4262 \\
\text { VI }\end{array}$ & $\begin{array}{l}\text { Hardee } \\
\text { VIII }\end{array}$ & \\
\hline & \multicolumn{6}{|c|}{$\longrightarrow \mathrm{kg} \mathrm{ha}^{-1}$} \\
\hline $\begin{array}{l}\text { Kuiaha }(320) \\
\text { Haleakala (660) } \\
\text { Olinda (1050) }\end{array}$ & $\begin{array}{l}85 \\
62 \\
95\end{array}$ & $\begin{array}{l}82 \\
71 \\
98\end{array}$ & $\begin{array}{l}85 \\
65 \\
98\end{array}$ & $\begin{array}{l}70 \\
66 \\
98\end{array}$ & $\begin{array}{l}80 \\
68 \\
96\end{array}$ & $\begin{array}{l}80 \mathrm{~B} \ddagger \\
66 \mathrm{C} \\
97 \mathrm{~A}\end{array}$ \\
\hline Mean & $81 \mathrm{abt}$ & $84 a$ & $83 a$ & $78 b$ & 82ab & \\
\hline
\end{tabular}

+ Indicates maturity group designation of the variety.

‡ Data followed by the same letter within the column or row are not significantly different $(P=0.05)$ by Duncan's Multiple Range test.
Table 5. Average rate of $\mathbf{N}$ assimilation by five nodulating soybean varieties grown at three different elevations.

\begin{tabular}{|c|c|c|c|c|c|c|}
\hline \multirow[b]{2}{*}{$\begin{array}{l}\text { Site } \\
\text { (elevation, m) }\end{array}$} & \multicolumn{5}{|c|}{ Varieties } & \multirow[b]{2}{*}{ Mean } \\
\hline & $\begin{array}{l}\text { Clay } \\
00 \dagger\end{array}$ & $\begin{array}{c}\text { Clark } \\
\text { IV }\end{array}$ & $\begin{array}{l}\text { D68- } \\
\text { O099 } \\
\text { VI }\end{array}$ & $\begin{array}{c}\text { N77. } \\
4262 \\
\text { VI }\end{array}$ & $\begin{array}{l}\text { Hardee } \\
\text { VIII }\end{array}$ & \\
\hline & \multicolumn{6}{|c|}{$\longrightarrow \mathrm{kg} \mathrm{ha}^{-1} \longrightarrow$} \\
\hline $\begin{array}{l}\text { Kuiaha (320) } \\
\text { Haleakala (660) } \\
\text { Olinda (1050) }\end{array}$ & $\begin{array}{l}3.23 \\
2.56 \\
0.48\end{array}$ & $\begin{array}{l}3.64 \\
2.67 \\
0.93\end{array}$ & $\begin{array}{l}3.51 \\
2.68 \\
1.14\end{array}$ & $\begin{array}{l}2.76 \\
2.45 \\
1.45\end{array}$ & $\begin{array}{l}3.29 \\
2.36 \\
1.08\end{array}$ & $\begin{array}{l}3.29 \mathrm{~A} \ddagger \\
2.55 \mathrm{~B} \\
1.02 \mathrm{C}\end{array}$ \\
\hline Mean & $2.09 \mathrm{~b} \ddagger$ & $2.41 a$ & $2.44 a$ & $2.22 \mathrm{~b}$ & $2.24 b$ & \\
\hline
\end{tabular}

† Indicates maturity group designation of the variety.

† Data followed by the same letter within the column or row are not significantly different $(P=0.05)$ by Duncan's Multiple Range test.

stant for all varieties within a site except for N774262 at 320 $\mathrm{m}$. The greatest soil $\mathrm{N}$ uptake was observed at the Haleakala site $(660 \mathrm{~m})$ in agreement with in vitro mineralization measurements (Table 7). Soil $\mathrm{N}$ uptake at Olinda $(1050 \mathrm{~m})$ was negligible. While actual soil $\mathrm{N}$ uptake was comparable with the estimated amounts of mineralized $\mathrm{N}$ at Kuiaha, it was reduced to a half and to less than a tenth at Haleakala and Olinda, respectively. The rate of plant $\mathrm{N}$ uptake in the greenhouse experiment from the soils of the two higher sites was similar to estimated rates of mineralization (Table 8).

\section{DISCUSSION}

We were able to test the effect of elevation-associated temperature differences on the performance of soybean genotypes belonging to a range of maturity groups in terms of yield, symbiotic $\mathrm{N}_{2}$ fixation, and soil $\mathrm{N}$ uptake. By planting the same day at different elevations in the same latitude, we minimized inter-

Table 7. Comparison of estimated amounts of mineralized $\mathbf{N}$ and actual soil $\mathbf{N}$ uptake by five soybean varieties at three elevations. $\dagger$

\begin{tabular}{|c|c|c|c|c|c|c|}
\hline \multirow[b]{2}{*}{ Varieties } & \multicolumn{2}{|c|}{ Kuiaha, $320 \mathrm{~m}$} & \multicolumn{2}{|c|}{ Haleakala, $660 \mathrm{~m}$} & \multicolumn{2}{|c|}{ Olinda, $1050 \mathrm{~m}$} \\
\hline & $\begin{array}{l}\text { Mineral- } \\
\text { izable N }\end{array}$ & $\begin{array}{l}\text { Soil N } \\
\text { uptake }\end{array}$ & $\begin{array}{l}\text { Mineral- } \\
\text { izable } \mathbf{N}\end{array}$ & $\begin{array}{l}\text { Soil N } \\
\text { uptake }\end{array}$ & $\begin{array}{l}\text { Mineral- } \\
\text { izable N }\end{array}$ & $\begin{array}{l}\text { Soil N } \\
\text { uptake }\end{array}$ \\
\hline & & & $-\mathbf{k g}$ & $1-b^{1}$ & & \\
\hline Clay & 46.8 & 37.0 & 145.1 & 76.7 & 37.1 & 2.2 \\
\hline Clark & 56.0 & 58.6 & 169.3 & 70.4 & 41.9 & 2.3 \\
\hline D68-0099 & 57.7 & 47.7 & 184.4 & 95.3 & 43.7 & 2.7 \\
\hline N77-4262 & 59.8 & 78.6 & 191.0 & 88.7 & 48.5 & 4.8 \\
\hline Hardee & 66.1 & 67.9 & 211.8 & 87.5 & 50.4 & 4.8 \\
\hline
\end{tabular}

$\dagger$ Mineralizable $\mathrm{N}$ estimated from the soil incubation study $\left(25^{\circ} \mathrm{C}, 3.0 \times\right.$ $10^{4} \mathrm{~Pa}$ ) and adjusted for soil temperature and the duration of crop growth. [For details of calculation, see Stanford et al. (1973, 1974).] Actual soil $\mathbf{N}$ uptake is the $\mathbf{N}$ content of non-nodulating plants.

Table 8. Nitogen uptake by Clark non-nodulating plants grown in three soils in the greenhouse at a mean soil temperature of $27^{\circ} \mathrm{C}$.

\begin{tabular}{|c|c|c|}
\hline Soils & $\begin{array}{c}\text { Estimated rate of } \mathbf{N} \\
\text { mineralization } t\end{array}$ & $\begin{array}{c}\text { Rate of } \mathbf{N} \text { uptake } \\
\text { by shoot } \$\end{array}$ \\
\hline & $-\mathrm{g} \mathrm{N}$ & $\mathrm{A}^{-1}$ \\
\hline $\begin{array}{l}\text { Kuiaha } \\
\text { Haleakala } \\
\text { Olinda }\end{array}$ & $\begin{array}{l}0.39 \\
1.29 \\
0.34\end{array}$ & $\begin{array}{l}1.02 \\
1.31 \\
0.47\end{array}$ \\
\hline
\end{tabular}

$\dagger$ Estimated from soil ineubation study $\left(25^{\circ} \mathrm{C}, 3.0 \times 10^{4} \mathrm{~Pa}\right)$.

$\ddagger$ Calculated from the $\mathrm{N}$ uptake from $4 \mathrm{~kg}$ of soil (oven-dry basis) by two plants after $45 \mathrm{~d}$ (pod-fill) of growth. 
actions between photoperiod and temperature affecting plant growth and development.

The reductions in yield (Table 2), total $\mathrm{N}$ assimilation (Table 3 ), and amounts of $\mathrm{N}$ fixed (Table 4) were substantial with a relatively small decline in temperature. It is unlikely that the differences in irradiance between sites accounted for the reduction in yield and total plant $\mathrm{N}$ of the magnitude observed in our experiments. Despite similar irradiances at the 660and 1050-m elevations, there were large differences in yield and $\mathrm{N}$ accumulation between these two sites. Since nutrients other than $\mathrm{N}$ and water were supplied in non-limiting amounts, the reduction in yield is assumed to be mainly due to decreasing temperature. Low temperatures may have adversely affected photosynthesis and nutrient assimilation processes.

Total $\mathrm{N}$ assimilation and the amount of $\mathrm{N}$ fixed were highly correlated with seed yield. Crop durations increased with maturity group number as well as with decreasing temperature (data not shown). Increased crop duration was due mainly to an extended vegetative phase and was correlated with seed yield within a site. Thus, the increase in yield and total $\mathrm{N}$ with increasing maturity group number was due to prolonged periods of photosynthesis, soil $\mathrm{N}$ uptake, and $\mathrm{N}_{2}$ fixation. Though, total $\mathrm{N}$ and yield increased with maturity group number, the average rate of $\mathrm{N}$ assimilation $(\mathrm{kg}$ $\mathrm{N}$ ha-'d-') (Table 5) was not related to maturity differences between varieties within a site. The large reductions in growth and $\mathrm{N}$ assimilation per day with increasing elevation indicate the effect of temperature on crop growth and $\mathrm{N}$ requirement, and, in turn, on $\mathrm{N}$ assimilation as suggested by Raper et al. (1977). Yield and $\mathrm{N}$ accumulation of early maturing varieties were more reduced by elevation compared to longer maturing varieties, probably due to the short vegetative durations.

The fact that $97 \%$ of the plant $\mathrm{N}$ requirement of nod isolines at Olinda was met by symbiotic fixation and that variety N77-4262 fixed similar amounts of $\mathrm{N}$ at all sites suggests that the effect of temperature was far greater on plant growth than on the process of symbiotic $\mathrm{N}_{2}$ fixation. The similar concentrations of $\mathrm{N}$ across all sites in stover (1.196) and grain (6.396) of nod isolines also indicate that the observed decrease in yield is not primarily due to low temperature limiting symbiotic $\mathrm{N}_{2}$ fixation but due to a direct effect of temperature on overall plant growth.

The proportions of $\mathrm{N}$ derived from fixation (Table 6) within a site were similar despite large differences in total $\mathrm{N}$ assimilation between maturity groups. Since the different maturity groups had similar average $\mathrm{N}$ assimilation rates per day within a site, and since soil $\mathrm{N}$ mineralization rate per day at a site can be assumed to be constant, the proportion of total $\mathrm{N}$ derived from $\mathrm{N}_{2}$ fixation necessarily is constant. This is reasonable since we have shown that soil $\mathrm{N}$ availability and uptake are functions of soil and temperature, and, within a site, temperature was relatively constant for the different maturity groups.

Soil $\mathrm{N}$ uptake at Olinda was negligible as determined by the total $\mathrm{N}$ of the non-nod isolines (Table 7). The lab mineralization study indicated that under controlled conditions, the $\mathrm{N}$ mineralization rate of the
Olinda soil was similar to that of Kuiaha. The tissue $\mathrm{N}$ concentrations of non-nod isolines at Olinda indicated they were severely stressed for $\mathrm{N}$. The greenhouse pot test at a higher mean soil temperature than that in the field indicated that non-nod plants grown in Olinda soil could assimilate substantial amounts of $\mathrm{N}$ (Table 8).

The nod isolines at Olinda, with little available soil $\mathrm{N}$, assimilated substantial amounts of $\mathrm{N}$, and the tissue $\mathrm{N}$ concentrations of nod isolines did not differ between sites. How low soil $\mathrm{N}$ availability affected $\mathrm{N}_{2}$ fixation at Olinda cannot be determined from our experiments. We may then assume that temperature mainly affected photosynthesis and requirement for $\mathrm{N}$ in the case of the nod isolines.

Considering the complexity of factors that may affect soil $\mathrm{N}$ availability and plant uptake, there are two reasonable temperature-related explanations for the low soil $\mathrm{N}$ uptake observed. During field preparation soil $\mathrm{N}$ might have been immobilized due to incorporation of organic material, and immobilization may have been prolonged due to low soil temperatures. However, the primary tillage operations were carried out 4 wks. before planting at all the sites, yet more soil $\mathrm{N}$ was available at the Haleakala site even though the soil temperature there was lower than that at the Kuiaha site. Another possibility might have been a differential tolerance to temperature of soil $\mathrm{N}$ assimilation and $\mathrm{N}_{2}$ fixation, such that root growth and uptake of soil $\mathrm{N}$ or assimilation processes, or both, were affected more than the latter. Rufty et al. (1981) reported that root growth and nitrate absorption were less at $18^{\circ} \mathrm{C}$ than at $24^{\circ} \mathrm{C}$. In contrast, soybean nodules have been reported to have maximum activity between 15 and $30^{\circ} \mathrm{C}$ (Pankhurst and Sprent, 1976). Thus, the $\mathrm{N}_{2}$ fixation process itself may not have been as seriously affected by the range of temperature in our experiments as was mineral $\mathrm{N}$ assimilation.

The different behavior of N77-4262 is of interest. Although yield and $\mathrm{N}$ accumulation of N77-4262 were relatively low at the lowest site, this variety was less affected by temperature than were other varieties. This variety fixed similar amounts of $\mathrm{N}$ at the lowest and highest sites. Our results indicate that this indeterminate variety may be suited for a wide range of temperature regimes at this latitude.

Our results demonstrate the dependence of soybean growth and $\mathrm{N}$ assimilation on temperature in the field. Decreasing temperatures caused greater restrictions on plant growth and dry matter production than on the functioning of symbiotic $\mathrm{N}_{2}$ fixation. The relative contribution of symbiotic $\mathrm{N}_{2}$ fixation was a function of soil- $\mathrm{N}$ availability at a site regardless of crop duration and total $\mathrm{N}$ accumulation by different varieties. Nitrogen assimilation per unit time was relatively constant for maturity groups within a site despite large differences in total $\mathrm{N}$ accumulation.

\section{ACKNOWLEDGMENTS}

The research was supported in part by the U.S. Agency for International Development grant no. DAN-0613-C-002064-00 (NifTAL Project) and Indo/US Initiative on Science and Technology grant no. DAN-1406-G-SS-4081-00. 
Conclusions of this paper do not necessarily reflect those of the granting agencies.

The authors gratefully acknowledge the suggestions made by D. P. Bartholomew, and field assistance provided by K. Keane and R. Koglin.

\section{REFERENCES}

Borthwick, H.A., and M.W. Parker. 1939. Photoperiodic responses of several varieties of soybeans. Bot. Gaz. (Chicago) 101:341-365.

Cassman, K.G., and D.N. Munns. 1980. Nitrogen mineralization as affected by soil moisture, temperature, and depth. Soil Sci. Soc. Am. J. 44:33-1237.

Earley, E.B., and J.L. Canter. 1945. Effect of the temperature of the root environment on growth of soybean plants. Agron. J. 37:727735.

George, T., B.B. Bohlool, and P.W. Singleton. 1987. Bradyrhizobium japonicum-environment interactions: Nodulation and in terstrain competition in soils along an elevational transect. Appl. Environ. Microbiol. 53:1113-1117.

Harding, S.C., and J.E. Sheehy. 1980. Influence of shoot and root temperature on leaf growth, photosynthesis and nitrogen fixation of lucerne. Ann. Bot. (Lonon) 45:229-233.

Keeney, D.R., and D.W. Nelson. 1982. Nitrogen-inorganic forms. In A.L. Page et al. (ed.) Methods of soil analysis. Part 2. Agronomy 9:643-698.

Matthews, D., and P. Hayes. 1982. Effect of root zone temperature on early growth, nodulation and nitrogen fixation in soybeans. J. Agric. Sci. 98:371-376.

McIntosh, M.S. 1983. Analysis of combined experiments. Agron. J. 75:153-155.
Pankhurst, C.E., and J.I. Sprent. 1976. Effects of temperature and oxygen tension on the nitrogenase and respiratory activities of turgid and water-stressed soybean and french bean root nodules. J. Exp. Bot. 27:1-9.

Parkinson, M.S., and S.E. Allen. 1975. A wet oxidation procedure suitable for the determination of nitrogen and mineral nutrients in biological material. Commun. Soil Plant Anal. 6:1-11.

Raper, C.D., Jr., L.R. Parsons, D.T. Patterson, and P.1. Kramer. 1977. Relationship between growth and nitrogen accumulation for vegetative cotton and soybean plants. Bot. Gaz. (Chicago) 138:129-137.

Rufty, T.W., Jr., C.D. Raper, Jr., and W.A. Jackson. 1981. Nitrogen assimilation, root growth and whole plant responses of soybean to root temperature, and to carbon dioxide and light in the aerial environment New Phytol. 88:607-619.

SAS Institute. 1982. SAS user's guide: Statistics. 1982 ed. SAS Institute, Inc., Cary, NC.

Schweitzer, L.E., and J.E. Harper. 1980. Effect of light, dark, and temperature on root nodule activity (acetylene reduction) of soybeans. Plant Physiol. 65:51-56:

Stanford, G., J.N. Carter, and S.J. Smith. 1974. Estimates of potentially mineralizable soil nitrogen based on short-term incubations. Soil Sci. Soc. Am. J. 38:99-102

M.H. Frere and D.H. Schwaninger. 1973 Temperature coefficient of soil nitrogen mineralization. Soil Sci. 115:321-323.

Ta lor, A.D., and J.A. Rowley. 1971. Plants under climatic stress. 7 Low temperature, high light effects on photosynthesis. Plant Physiol. 47:713-718

Tolley,, L.C., and C.D. Raper, Jr. 1985. Cyclic variations in nitrogen uptae rate in soybean plants. Plant Physiol. 78:320-332.

Trang, KM., and J. Giddens. 1980. Shading and temperature as environmental factors affecting growth, nodulation, and symbiotic $\mathrm{N} 2$ fixation by soybeans. Agron. J. 72:306-308. 